DOI:

\title{
TACTIC OF PRAGMATIC ADAPTATION IN TRANSLATING TOURISTIC TEXTS
}

\author{
Said Mamedov \\ Federal State Autonomous Educational Institution of Higher Education Lobachevsky State «University of \\ Nizhny Novgorod - National Research University» Arzamas Branch \\ (Arzamas, Russia) \\ saidmamedow@yandex.ru
}

\begin{abstract}
The article deals with the tactics of translation used in the field of tourism, the tactics of pragmatic adaptation and the tactics of transmission of the main relevant information in particular. Practical examples confirming the relevance of the use of the above-mentioned tactics in translating touristic texts are given.
\end{abstract}

Keywords: tourism, communicative situation of translation, translation, translation strategies and tactics, translation operations

\section{ТАКТИКА ПРАГМАТИЧЕСКОЙ АДАПТАЦИИ ПРИ ПЕРЕВОДЕ ТЕКСТОВ ТУРИСТИЧЕСКОЙ ДЕСТИНАЦИИ}

\author{
Саид Заурович Мамедов \\ Федеральное государственное автономное образовательное учреждение высшего образования \\ «Национальный исследовательский Нижегородский государственный университет \\ им. Н.И. Лобачевского» Арзамасский филиал \\ (Арзамас, Россия) \\ saidmamedow@yandex.ru
}

\begin{abstract}
Аннотация. В статье рассматриваются тактики перевода, применяемые в сфере туризма, в частности тактика прагматической адаптации и тактика передачи основной релевантной информации. Приведены практические примеры, подтверждающие актуальность использования вышеуказанных тактик при переводе текстов туристической дестинации.
\end{abstract}

Ключевье слова: туризм, коммуникативная ситуация с использованием перевода, перевод, стратегии и тактики перевода, переводческие операции

INTRODUCTION. According to the communicative-functional approach, translation, like any other speech activity, is performed in a certain communicative situation (Sdobnikov 2015); thus, the translation strategy is chosen according to the purpose of the translation, the needs and expectations of the recipients and the initiator, the conditions for the implementation of these subjects of their substantive activities.

In the real world there is an unlimited number of communicative situations, each of which is unique and specific. The concept of "communicative situation" is correlated with the concepts of "act of speech communication" or "speech event", although being somewhat wider. According to R. O. Jacobson, in the model of communication, or speech event, the addresser (speaker) and the addressee (listener) participate; from the first to the second one a certain message written with the help of a code is transmitted; the context is associated with the content of this message, with the information transmitted by it, as well as with the situation in the surrounding reality. The concept of contact, in its turn, is associated with the regulatory aspect of communication, its establishment, maintenance and completion(Jacobson, 1975).

Within one and the same sphere of life of activity different communicative situations may arise. For example, earlier we have identified the following types of communication situations in relation to the tourism industry:

Hospitality (arrival, registration, accommodation of the client in the hotel, short-term contacts with clients, a range of services, meals, departure, customer payment at check-out).

Meals/Food and beverage (Breakfast, lunch, dinner in a restaurant, cafe, food court; catering).

Marketing communications (promotions, bonus programs).

Communication "travel Agency - tourist/client" (selection, presentation and design of the tour).

Communication "travel Agency - tour operator" (proposals for the organization of various types of recreation).

Excursion (excursion program)

Communication situations taking place at the airport or train station (meeting and seeing tourists, information services, Shuttle service).

Advertising (brochures, catalogues, booklets, advertisements, promotional tours) (Mamedov, 2017).

If communication in the above-mentioned situations takes place in different languages, a cross-language and crosscultural communication arises, carried out with the help of a mediator, usually an interpreter, whose task is to help communicants inovercominglanguage and cultural barriers.

The need for translation in the field of tourism covers all possible forms of information: websites, catalogues, booklets, menus, leaflets or signs related to the tourism industry, which means that the need for interpreters arises from the staff of airports, hotels, restaurants, museums, as well as from guides or tour operators seeking to best provide their 
services and meet the needs of tourists. Thus, in its turn means that each time a translation is made, the needs and expectations of the actual or potential recipients of the translated text must be taken into account.

LITERATURE REVIEW. The theoretical basis of this study were the works of V. V. Sdobnikov and R. O. Jakobson. As a practical material used to confirm the relevance of the use of tactics of pragmatic adaptation in in translating touristic texts, excerpts of hotel brochures, as well as elements of terminology used in the study area were used.

RESEARCH METHODS. The following research methods were used in the study: content analysis to analyze the texts of the tourist destination and their translation methods, descriptive method to describe the used lexical units and the method of communicative-pragmatic analysis.

RESULTS AND DISCUSSION. The general classification of communicative with the use of translations is presented in the works of V. V. Sdobnikov. The researcher distinguishes two types:

1. The Communicative situations of translation, in which the translation was intended, originally planned;

2. The Communicative situations of translation in which the translation was not originally planned (Sdobnikov, 2015).

Communicative situations of translation -1 , in their turn, are divided into subtypes depending on the degree of formality of relations between communicants. Accordingly, we can define the formalCommunicative situation of translation -1 (Communicative situation of translation $-1_{\text {formal }}$ ) and informal Communicative situation of translation -1 (Communicative situation of translation $-1_{\text {informal }}$ ).

Examples of Communicative situation of translation -1formal in the field of tourism are the following situations: business meetings and negotiations between multilingual representatives of the tourism sector; international lectures, seminars and trainings for specialists in the field of tourism; interviews with foreign travel agents, hotel employees and other structures of tourism business; excursions for foreign tourists; translation support of a foreign tourist in a hotel, restaurant, customs and other institutions, ordering tickets, etc.; translation of brochures, booklets, as well as documentation related to the work of tourism enterprises and business letters. In all these cases, the need for translation is realized in advance, the translation service is organized by the person responsible for the tourists' stay in a foreign country (in most cases it is the Manager of a travel agency/hotel).

Communicative situation of translation -1 of an informal nature (Communicative situation of translation $-1_{\text {informal }}$ ) means such communicative situations as a banquet with the participation of foreign specialists or communication among foreign specialists on production and non-production topics outside the working situation, including conferences among participants outside the framework of meetings, etc. (Sdobnikov 2015).

Another example- a corporate meeting of a hotel/travelagency employees (again with the participation of foreign specialists).

A vivid example of Communicative situation of translation -2 in the field of tourism is the situation when a tourism specialistbuys some professional (special) literature in a foreign language (due to the lack of such in his native language) and decides to order the translation of this manual; as we see, in this situation, the translation of literature was not initially planned.

In the field of tourism, as wells as in other fields of activity, one and the same text can be used in different communicative situations in accordance with different translation objectives and, accordingly, can be translated in different ways; in other words, when translating the same text in different communicative situations, the interpreter uses different translation strategies. According to V. Sdobnikov, translation strategy is a common programme for implementing translation activities in a particular communicative situation of bilingual communications, defined by specific features of the given situation and purpose of the translation and, in turn, defining the nature of professional conduct of the interpreter in the framework of the given communicative situation.

Therefore, the success of translation activity is determined by the right choice of the necessary translation strategy. V. V. Sdobnikov identifies three types of translation strategies: strategy of communicative translation, strategy oftertiary translation and redirection strategy (Sdobnikov 2015).

The communicative translation strategy is used when the aim of the original text and the text of the translation are the same. For instance, such situations as excursions, business meetings and negotiations between multilingual representatives of the tourism sector, international lectures, seminars and trainings for specialists in the field of tourism, interviews with foreign travel agents, employees of hotels and other structures of tourism business, translation support of foreign tourists in the hotel, restaurant, customs and other institutions, ticket booking, etc., translation of brochures (for foreign tourists), booklets, as well as documentation related to the work of enterprises of tourism business, and business letters, etc. since it is obvious that in these situations the purpose of the translation is to provide the necessary information and have a similar (emotional and psychological) impact on the recipient, in our case - a tourist/foreign travel agent or other employee of the tourism sector.

For example, when organizing a tour for foreign tourists, the purpose of translation is similar to the purpose of the original; the task of the interpreter is the same as the task of the author of the original (in this case - the guide) providing information to the tourist and, as already mentioned, having a similar emotional and psychological impact, i.e. to interest the client and make the tour interesting and exciting.

The same applies to the situation of training the specialists in this field: the purpose of both the author of the original and the interpreter in this case is to provide foreign workers with certain information and to teach them new skills concerning tourism industry and business. Since a foreign specialist performs the role of a "student" in this situation, it will be important to have an appropriate emotional and psychological impact on him.

As for the second type of Communicative situation of translation (Communicative situation of translation -2), the purpose of the translation depends on the special needs of the translation initiator in the framework of its substantive 
activities. Among the initiators of the translation, we include the author of the original text, the potential recipient of the translation, the translation receiver and the interpreter, because their needs determine the nature (type) of the translation strategy; in this case, we distinguish between the potential recipient of the translation and the customer of the translation. However, it should be borne in mind that the needs of the recipient of the original may not be different from the needs of the recipient of the translation, so, the strategy of communicative translation can be used there.

As an example, the above mentioned situation with the translation of brochures and guidebooks for foreign tourists may be given, but only if this translation was not initially planned. For example, a travel company buys a brochure/guidebook (in electronic form for instance) and orders its translation for displaying on the website.

However, the strategy of communicative translation is not the only strategy that can be used in Communicativesituationsoftranslation-2; the strategy of tertiary translation is also applicable when the translation text is not designed to have an impact similar to that of the original. Speaking about the field of tourism, the example may be the following: the sender of the source text - an author of a tourist brochure (originally designed for tourists), the recipient of the translation of this brochure is, forexample, a foreign business-partner; this type of recipient needs only "pure" information about the hotel's objects and facilities necessary for further cooperation. Thus, the function of translation in this case - the impact only on the recipient's consciousness, that is, the text of the translation all emotional and expressive means available in the text of the original (whose purpose is not only to provide the recipient with certain information, but also to have an emotional and psychological impact and, accordingly, to convince him to use the services of this company), will be omitted ("Our holding includes two recreation centers in the forest, one children's camp on the river, two hotels...").

One of the tactics by which this strategy is implemented is the tactics of transferring the main relevant information.

Let's consider some practical examples:

1. An excerpt from the hotel brochure (Park Inn hotel, St. Petersburg):

«Санкт-Петербург - это один из самых уникальных и красивых в мирегородов, и Петро Палас Отель находится в самом его сердце.»

As already mentioned, foreign business partners need only "pure" information, respectively, one of the translation options in this case will be as follows: "the hotel is located in the center of St. Petersburg, a famous Russian city."

2. An Information brochure "mon Repo Palace", presidential suites room type description: «Вединомипросторномпомещениивампредлагаетсякомфортвклассическихтонах. Гостиная, большая спальня с одной двуспальной кроватью,ванная комната с ванной или душевой кабинкой и богатый спектр услугсоставляют обстановку существенной роскоши. Просторная меблированнаяверанда дает вам возможность смотреть на бесконечную синеву залива Горица

и магический город Корфу. Наслаждайтесь заботой нашего опытного персоналаи поддайтесь своим чувствам».

Again, when translating the Russian original into English, performed for foreign partners, as in the previous examples, all emotional and expressive means will be pubescent; the first sentence is enough to translate as follows: "the combined Suite is made in the classical style." Further - " consists of a bedroom with living room, large double bedroom, bathroom with bath/shower ...". The next offer is "a large furnished veranda with views of the Gorica Strait and the city of Corfu".

3. An excerpt from the hotel brochure "Park Plaza" (Cardiff):

Each of the hotel's 129 stunning rooms has been thoughtfully designed using a variety of luxurious fabrics and fittings and the latest fashion cons for your comfort. The air-conditioned rooms at Park Plaza Cardiff feature a flat-screen TV, a Minibar, tea / coffee making facilities, a Hairdryer, an iron with Ironing Board and a laptop safe.

Of course, in the translation intended for foreign partners, such expressive means as "stunning", "summary" or "latest-mod-cons for your comfort" will be omitted; as in all previous examples, only "dry" information: «129 комнатсовременногодизайна... всекомнатыоснащены (оборудованы) кондиционерами, минибарами, кофемашинами, гладильнымидосками, утюгами, фенамиисейфами».

Anotherimportanttacticnecessaryfortranslatingtouristictextsistacticofproperinformationprocessing (Sdobnikov, 2015); ignoring this tactic may confuse the translation receiver because of some barriers connected within formation processing rules and realties. Forexample, translating the English phrase «This year we stayed at Radisson» into Russian as «B этом году мы отдыхали в Рэдиссоне» would not beright astherecipientmaynotk now exactly what Radissonis (a town/a company/a hoteletc.), thustherightvariantis «В этом году мы отдыхали в отеле «Рэдиссон» asaccordingtotherulesoftheRussianlanguage, namesofcompaniesshouldbeputbetweenquotationmarks. Moreover, attentionshouldalsobepaidtothewordorder, forinstance «Marriotthotel» (English) - «Отель Марриот» (Russian)

Onemoretranslationmethod, usedwithinthistacticisconnectedwith using explanations, suchas:

The phrase "Нижегородскаяземля, родинаВалерияПавловичаЧкалова" (Russian); it's clear that foreign tourists do not know who the above-mentioned person was, so, when translating this phrase into a foreign language, this should be clarified, that is, the translation may look as follows:".....homeland of a famous Russian pilot Valeri Pavlovich Chkalov..". In the case of written translation, this information may be included in a footnote.

Another example of descriptive translation: in one of the guidebooks, the Italian term Villanoviani is translated as follows - 'ancient tribes of the Villanova zone' (the so-called Villanoviani).

Attention must be alsopaidtopropertranscribingandtransliteratingspecifictermsespeciallynames, such as

«Стамбул» (Russian) whichistheappropriatetranslationforIstanbul (not «Истанбул»)

or «компания «Майкрософт» (Russian), not «Микрософт».

Let'sconsider a fewmoreexamplesoftransliteration: 
infrastructure - инфраструктура; bank - банк;

factor - фактор; capital - капитал;

liberalization - либерализация; credit - кредит;

sector - сектор; parliament - парламент;

Austria - Австрия;

Alps - Альпы;

Habsburg Dynasty's - Габсбургская династия;

the Beatles - Биттлз;

Sony - Сони;

theGuardian - Гардиан (ежедневная британская газета);

Manchester United - «Манчестер юнайтед» (британский футбольный клуб)

Whentransliterationissomehowimpossibleorunacceptable, anothermethodcanbeused - calculus is the reproduction not of sound, but of combinatorial composition of a word or phrase, when the components of a word (morpheme) or phrase (lexeme) are translated by the corresponding elements of the translating language.

Head of the government - главаправительства;

massculture - массовая культура;

basiclaw - основной закон, конституция;

non-confidence vote - вотумнедоверия;

Federal Constitutional Court - Федеральный Конституционный суд;

Roman law - Римскоеправо;

The Democratic Party - Демократическая партия;

Human rights - права человека;

inflation 'инфляция', foreignsuppliers 'иностранные поставщики', tariff systems 'тарифные системы', exportimport documentation 'экспортно-импортная документация’.

As weallknow, the information is adapted to the speakers of not only a different language, but also a different culture; accordingly, when translating touristic texts it's often necessary to deal with certain realities (especially national-specific ones), which are quite difficult to translate or untranslatable at all; as we know, hidden cultural and linguistic difficulties cause great problems. According to S. G. Ter-Minasova, "words are a veil over real life, a kind of web, a curtain". The user needs to look behind the 'curtain of words' in a foreign language, to understand where the 'paths of word meanings' lead (Ter-Minasova 2007). Therefore, in this case it is appropriate to talk about one more tactic - the tactic of pragmatic adaptation of the text (Sdobnikov 2015).The most used methods of translation, aimed at implementingthis tactic, aswesee, are transcription, transliteration, descriptive translation, the use of footnotes (in written tra.nslation)andreducingtheinformation, unnecessary for particular recipients and in particular commun icative situations. And it's clear that pragmatic adaptation is necessary even if tgeaimsof the original text and the text of the translation are the same becaus eit is still necessary to reproduce some realities, terms or events and make them clear to recipients (see the above-mentioned examples).

CONCLUSION. The above mentioned examples reveal the relevance of the use of tactic of pragmatic adaptation while translating touristic texts in accordance with the types of recipients of translation, their needs and requirements, thus, due to the type of the Communicative Situation of translation, in accordance with which the necessary translation methods (strategies - tactics-operations) are chosen.

\section{LIST OF REFERENCES}

Sdobnikov, V.V. Perevod i kommunikativnaya situatsiya: monografiya [Translation and Communicative Situation: Monograph]. Moscow, FLINTA, Nauka Publ., 2015. 464 p.

Jacobson R.O. Lingvistika poeta // Strukturalizm: za i protiv: Sbornik nauchnyh statej [Poet Linguistics // Structuralism: for and against: Collection of scientific articles]. Moscow: Progress, 1975, P. 193-230

Mamedov S.Z. Vidy diskursa v sfere turizma. Problemy teorii, praktiki i didaktiki perevoda: Sbornik nauchnyh trudov. Seriya "Yazyk. Kul'tura. Kommunikaciya». [Discourse types in the field of tourism. Problems of theory, practice and didactics of translation: Collection of scientific papers. "Language. Culture. Communication.» Series].Issue 20 Volume II. Nizhny Novgorod: NGLU (Nizhny Novgorod State Linguistic University), 2017 P.183-189.

Ter-Minasova, S.G. Vojna i mir yazykov i kul'tur. [War and peace of languages and cultures.] - Moscow: Slovo/Slovo, 2007. - 287 p.

\section{For citation:}

Mamedov, S. (2019) TRANSLATION HEADACHES: R. BURNS WHA IS THAT AT MY BOWER-DOOR? AND S. MARSHAK. FINDLEY (Linguistic Commentary Experience). International Scientific-Pedagogical Organization of Philologists “ WESTEAST" (ISPOP). Scientific Journal WEST-EAST. Vol 1/1 N1 (October, 2019). pp. 166-170. doi:

\section{Для цитирования:}

Мамедов, С.3. (2019) ТРУДНОСТИ ПЕРЕВОДА: R. R. BURNS WHA IS THAT AT MY BOWER-DOOR? И C. МАРШАК. ФИНДЛЕЙ (опыт лингвистического комментария) // International Scientific-Pedagogical Organization of Philologists “ WEST-EAST" (ISPOP). Scientific Journal WEST-EAST. Vol 1/1 N1 (October, 2019). C. 166-170. doi: 
Information about the author: Said Mamedov - Federal State Autonomous Educational Institution of Higher Education Lobachevsky State «University of Nizhny Novgorod - National Research University» Arzamas Branch, Russia

saidmamedow@yandex.ru

Сведения об авторе: Саид Заурович Мамедов - Федеральное государственное автономное образовательное учреждение высшего образования «Национальный исследовательский Нижегородский государственный университет им. Н.И. Лобачевского» Арзамасский филиал, Россия saidmamedow@yandex.ru 